\title{
Radiofrequency Ablation of Symptomatic Non-Functioning Benign Thyroid Nodules: An Early Experience in Egyptian Patients Using Monopolar Electrodes
}

\author{
AHMED M. BASSIOUNY, M.D.* and MOHAMMED H. ABDELBARY, M.D.** \\ The Department of Radiology, Faculty of Medicine, Ain Shams* and Helwan** Universities, Cairo, Egypt
}

\begin{abstract}
Background: Thyroid nodules are noted as a common condition, some of them may need management for compressive effects or cosmetic reasons. As surgery has many disadvantages, minimally invasive procedures are taking place, particularly radiofrequency (RF) ablation that proved to be safe and effective since 2006.
\end{abstract}

Aim of Study: To study the safety and clinical results of (RF) ablation of benign non-functioning symptomatic thyroid nodules.

Methods: We assessed 27 non-functioning benign thyroid solid nodules in 20 patients, after treatment by radiofrequency (RF) ablation and follow-up for 12 months. RF ablation was done by Cool-Tip RF system and cooled internal electrode. Nodule volume, cosmetic and symptom scores were calculated earlier prior to treatment and throughout the follow-up. We assessed all efficacy related factors and reported complications.

Results: The mean follow-up duration was $11 \pm 2.6$ months The volume of the thyroid nodule decreased significantly at the final assessment from an average of $12.2 \mathrm{ml}$ before ablation to $6 \mathrm{ml}(p<0.001)$. Also there was markedly improved cosmetic and symptom ratings $(p<0.001)$. The overall rate of recurrence was $4 \%(1 / 27)$. The overall rate of complication was $3 \%$ $(6 / 20)$.

Conclusion: RF ablation is effective in decreasing the volume of sizable benign thyroid nodules for a one year postinterventional follow-up. There were no complications that threatened life. Thus, patients with non-functioning benign thyroid nodules can be treated by RF ablation as a minimally invasive treatment.

Key Words: Thyroid nodule-Benign-Cosmetic dissatisfaction - Pressure effects - Radiofrequency ablation Non-surgical management.

\section{Introduction}

THYROID nodules are noted as a common condition, diagnosis of nodular thyroid has amplified with the frequently increased usage of thyroid

Correspondence to: Dr. Ahmed M. Bassiouny, E-Mail: Ahmed bassiouny@hotmail.com ultrasonography (US) [1] . Inspite that most thyroid nodules are benign and need not be treated, some of them may need management for compressive effects as well as cosmetic dissatisfaction [2,3]. As surgery has many disadvantages [4] and thyroid hormone-suppressive therapy's efficacy was not well understood [5], minimally invasive procedures, such as laser, radiofrequency (RF) and ethanol (EA) ablations, are used to treat thyroid nodules. Ethanol ablation (EA) is effective in the treatment of cystic nodules and is noted to be of less effect in treatment of solid nodules [2,6]. Laser ablation has been studied mainly for solid nodules treatment [7]. Microwave ablation and High-Intensity Focused Ultrasound (HIFU) were also presented as new treatment strategies for thyroid nodules [8-10] For the treatment of benign thyroid nodules and persistent malignant thyroid nodules, RF ablation has been confirmed to be safe and effective since 2006.

In this study, we introduced our early experience of using radiofrequency ablation for 27 benign thyroid solid nodules aiming to provide an effective alternative option rather than surgery for many patients suffering from thyroid nodule-related compressive and cosmetic symptoms.

\section{Patients and Methods}

The institutional review board of Ain Shams and Helwan University Hospitals approved this study, our patients received written informed consent prior to the US-guided Fine Needle Aspiration Biopsy (FNAB) and RF ablation.

\section{1- Patients:}

Between March 2016 and April 2018, 27 solid thyroid nodules of 20 patients were ablated under US-guidance at Helwan University Hospitals. Pa- 
tients were included when they meet the following conditions: Cosmetic or compressive problems, such difficulty in swallowing or breathing; largest nodule diameter of more than $2 \mathrm{~cm}$; two ultrasound guided biopsies confirming that the nodule is benign; absence of suspicious US characteristics; normal ranges of full thyroid laboratory profile; refusal of or unfit for surgery. This ended by choosing 27 nodules of 20 patients ( 2 men, 18 women; age ranging between 19-69 years) who were subjected for a one year follow-up.

\section{2- Pre-ablation evaluation:}

Thyroid nodules were assessed by US examination, laboratory and FNAB. Diagnostic US, USguided biopsy and RF ablation were conducted using a 10-MHz linear probe (Aplio 400, Toshiba Medical System and Logic P9, GE medical systems). FNAB was performed four days before the RF session. Preceding the FNAB, proper history taking for certain drugs such as Aspirin or Plavix was carried out. Three measurements of each nodule in three orthogonal planes were measured prior to the procedure. The nodule volume was measured as $\mathrm{V}=\mathrm{n}$ abc/6 (where $\mathrm{V}$ is volume, $\mathrm{a}$ is the largest plane, while $b$ and $c$ are the two other planes). Vascularity of the nodule was classified using a scale of four points, with Doppler findings as follows: No Doppler signal, signals in less than $25 \%$ of the nodule, or $25-50 \%$ of the nodule and in more than $50 \%$ of the nodule. Laboratory tests included measurements of serum thyrotropin, total triiodothyronine, free thyroxine, and calcitonin concentrations, as well as platelet count, prothrombin time and activated partial thromboplastin time. Patients were asked to rate through a visual analogue scale from pressure symptoms and cosmetic complain on a (0-10) $[\mathbf{6 , 1 2}]$

\section{3-Procedure:}

We used an RF generator (Cool-Tip RF system, RF MEDICAL, Korea) and a 18 gauge internally cooled electrode having 7 and $10 \mathrm{~mm}$ active tips. All patients were given light sedation, A $2 \%$ lidocaine was given at the puncture site for local anesthesia. Also, 5\% dextrose solution was injected within the subcutaneous tissue planes at the puncture site for all patients (i.e Hydrodissection). Under US guidance, RF ablation was done through trans-isthmic approach and moving shot technique Fig. (1). In this technique we introduce the electrode to a distal location at the nodule in a given scanning plane. From the same puncture site, the ablation is performed from deep to superficial and from the lower pole upwards while the RF power is working during gentle withdrawal of the electrode. During the procedure, we consider to under ablate nodules in close vicinity to surrounding important structures, thus preventing serious complications such as nerve injury, tracheal or esophageal injury.

We started ablation by $30-80 \mathrm{~W}$ of RF power. If a transient echogenic zone Fig. (2) did not appear at the tip of the electrode within 5-10s, RF power is raised to a maximum of $120 \mathrm{~W}$ in $10 \mathrm{~W}$ increments, this is done according to the needle active tip size and the characters of the ablated nodule. If the patient was not able to withstand the discomfort during the ablation, for several seconds the power was decreased or turned off. Based on clinical signs and symptoms our complications were assessed during and after the procedure. When all targeted areas had become transient hyperechoic areas, the ablation process is then completed.

\section{Results}

Of the 20 patients, 2 men and 18 women, age ranging from 19 to 69 , all suffered from compressive symptoms or cosmetic complains prior to RFA, pre-treatment VAS (Table 1) average was 4.5 for compressive symptoms and 4.8 for cosmetic complains, 15 patients had both compressive symptoms and cosmetic complains, while 5 have cosmetic complains only.

In our study patients refusing surgical treatment are candidates for RFA. Prior to treatment 15 nodules measured $12-15 \mathrm{cc}(44.4-55.5 \%)$ while only 2 were $20 \mathrm{cc}(7.4 \%)$ and 10 nodules (37\%) measured from 8 to $10 \mathrm{cc}$.

Decreased vascularity was noted in all ablated nodules with variable degrees and were classified according to a 4 grades scale (Table 2) Fig. (3).

In our study success of the procedure was defined as a more than $50 \%$ decrease in the size of the nodule, thus improving the compressive and cosmetic complains Fig. (4).

Follow-up of the patients was done after 1 month, 3 months, 6 months and 12 months.

After RF ablation 13 patients (65\%) complaining of both compressive and cosmetic symptoms had marked improvement regarding the complaint and the size of the nodule, largest 2 nodules had regressive compressive symptoms but still had cosmetic complain (10\%), in patients with only cosmetic symptoms $3(15 \%)$ had satisfactory results while another 2 were not satisfied $(10 \%)$.

Decrease in average VAS was significant, down to 1 in patients with compressive symptoms and 2.3 in those with cosmetic symptoms (Table 3 ). 
Also decrease in size more than $50 \%$ of the ablated nodules was encountered in all nodules with mainly improvement of the compressive symptoms (Table 4).

In one case (4\%) of the 27 only $25 \%$ reduction in size in the first 3 months was noted followed by re-increase in size in the 12 months' follow-up.

Six of our cases had complications including pain during ablation, 3 cases had small hematomas. Pain is controlled by reducing the power or turning off the generator, while cases with small hematomas were controlled by compression and topical treatment for one week. No major complications were encountered.

Neither of our cases had skin burns as we used hydro dissection with $5 \%$ dextrose be- tween the thyroid gland and the subcutaneous tissue.

Other complications are thermal nerve injuries, nodule rupture, permanent change of voice is due to recurrent laryngeal nerve affection which we didn't face. Only one case had transient voice change that returned to normal within four days. In general, we always preferred in our study to under treat the regions adjacent to the recurrent laryngeal and vagus nerves. Similarly we kept at least $10 \mathrm{~mm}$ distance between the electrode and other important structures such as the esophagus and trachea.

Our results and pretreatment statistical analysis (Table 5) as well as comparative pre and post ablation studies regarding the regression in compressive, cosmetic effects and volume Figs. (5-8) were demonstrated graphically.

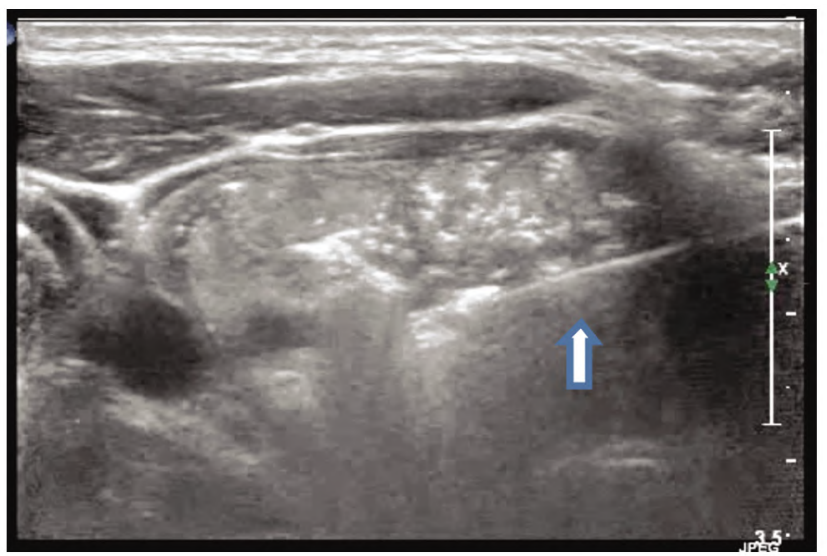

(A)

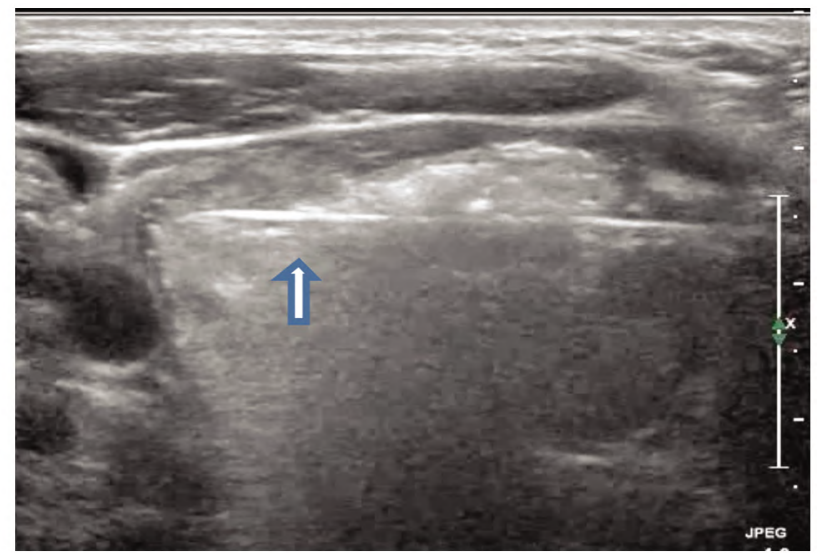

(B)

Fig. (1): Moving shot technique; left lobe thyroid nodule with RF needle inside (arrows) (A), and hyperechoic foci of ablation (B).

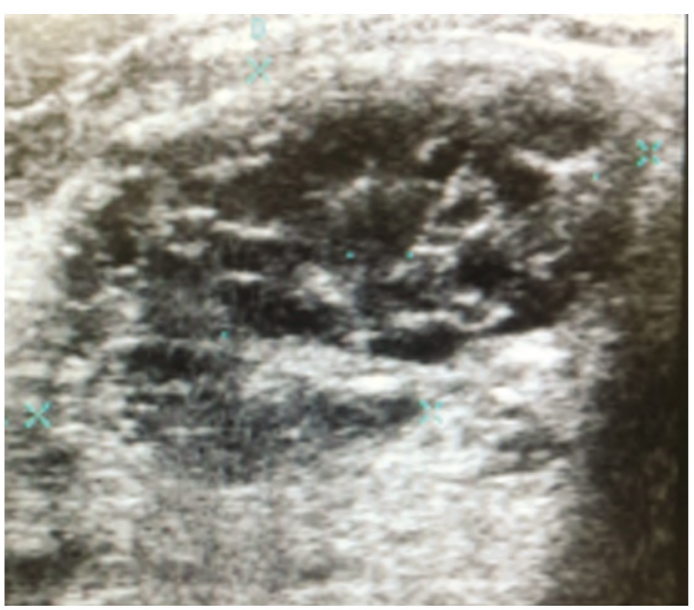

(A)

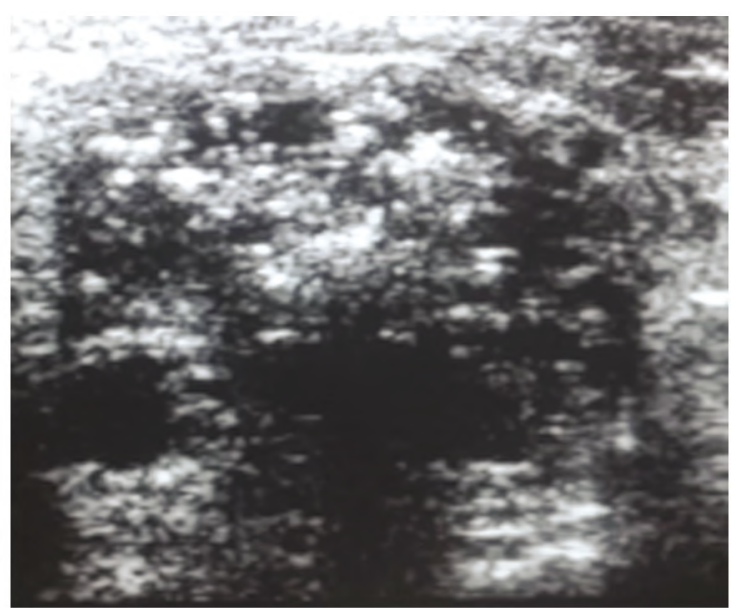

(B)

Fig. (2): Left lobe thyroid nodule pre (A), and post ablation with echogenic foci inside and uneven contour (B). 

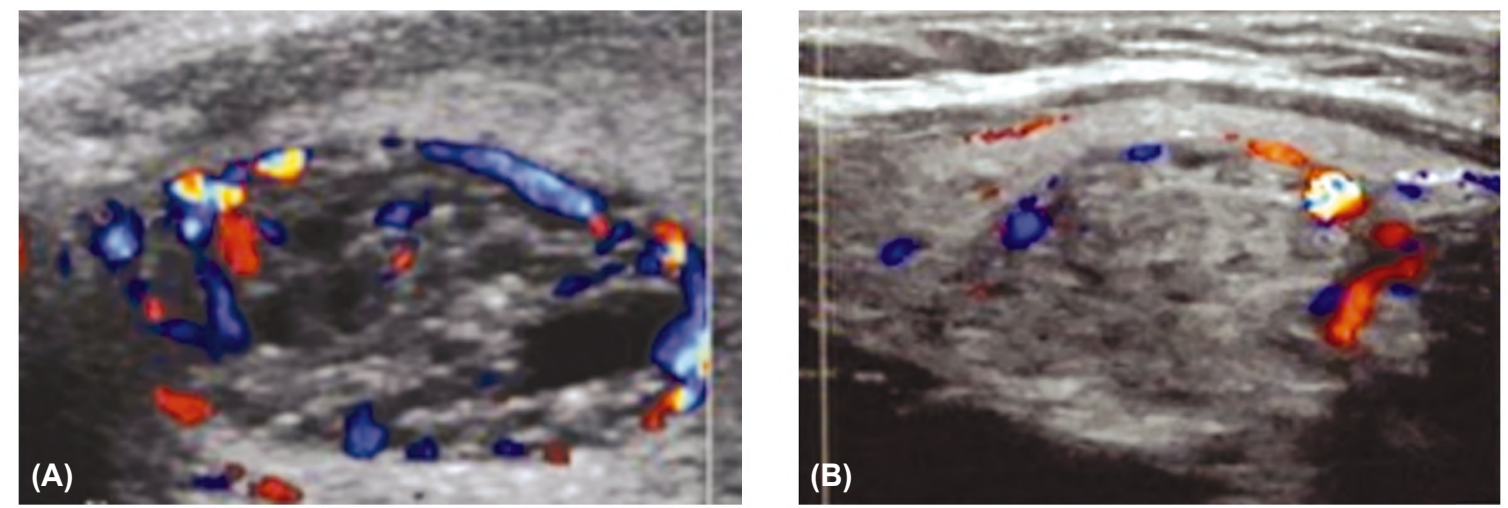

Fig. (3): Preablation thyroid nodule increased vascularity (A), and 6 months post ablation with decreased vascularity (B).

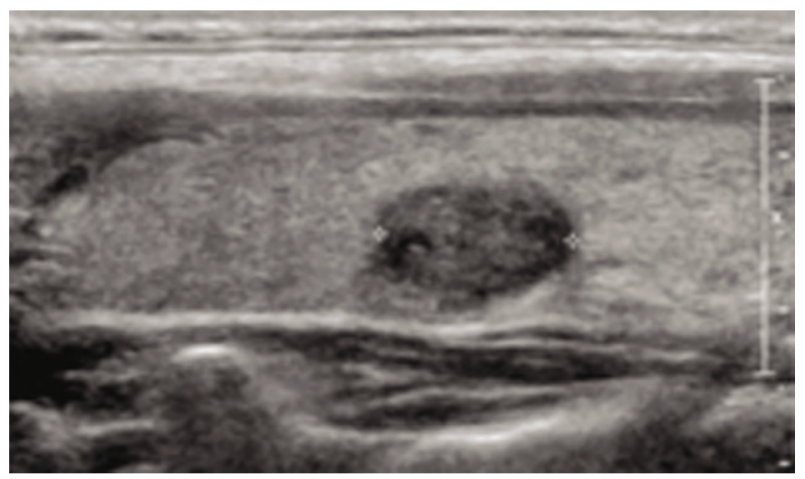

Fig. (4): Marked regressive size after 12 months follow-up.

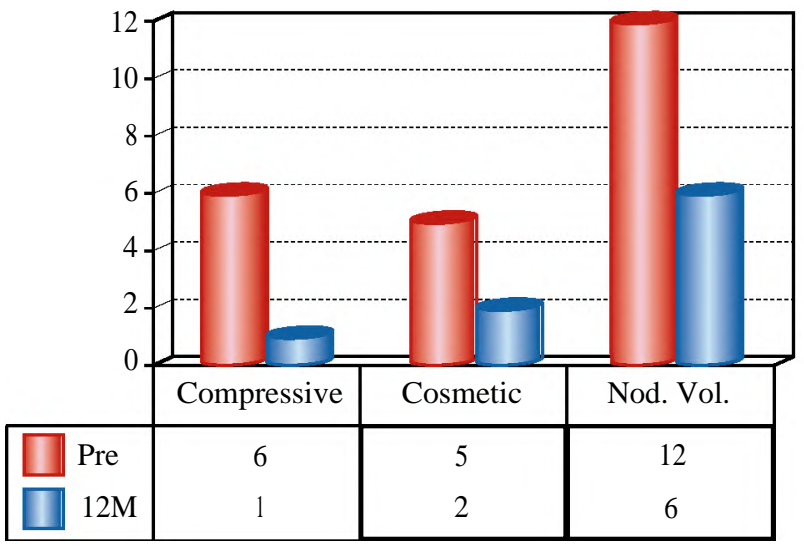

Fig. (5): Comparative study between pre and post-12M as regards compressive; cosmetic and nodule volume.

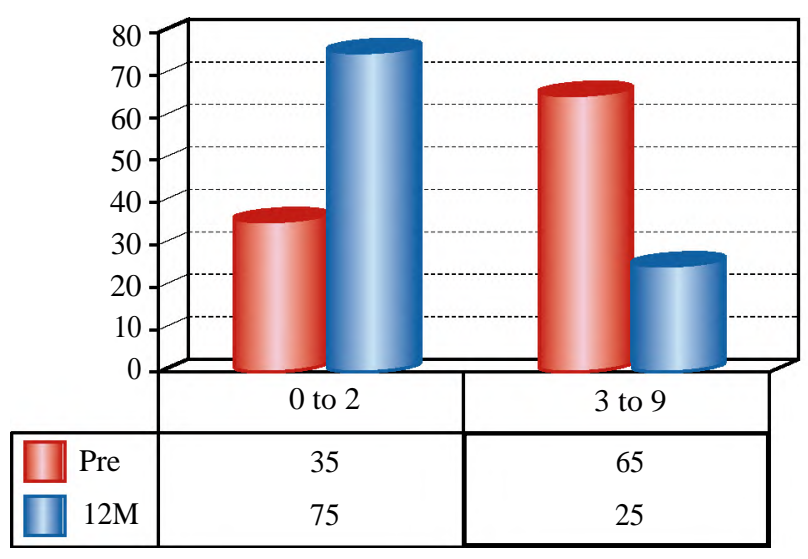

Fig. (7): Comparative study between pre and post-12M as regards cosmetic change.

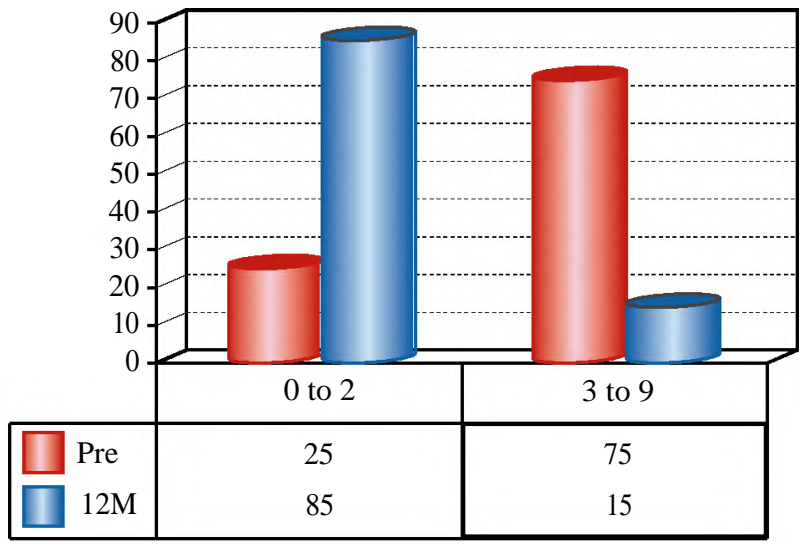

Fig. (6): Comparative study between pre and post-12M as regards compressive change.

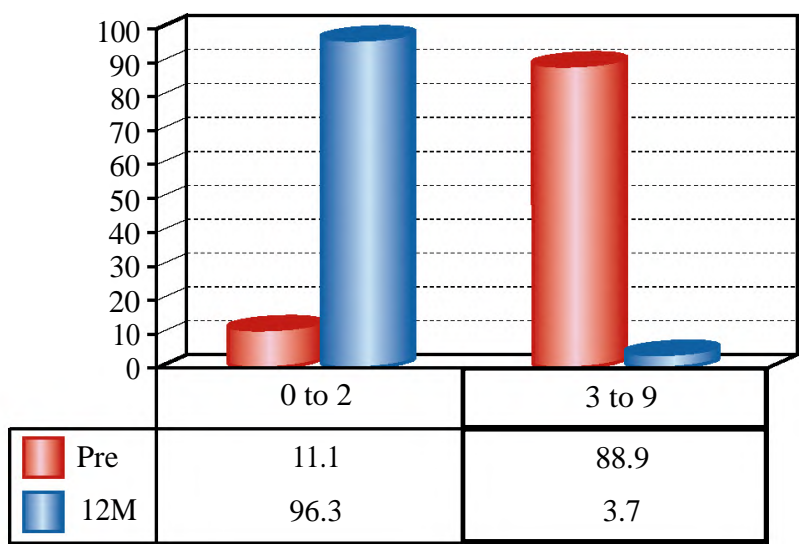

Fig. (8): Comparative study between pre and post-12M as regards nodule volume change. 
Table (1): Visual Analogue Scale for pain (VAS).

\begin{tabular}{llll}
\hline 0 & $1-2-3$ & $4-5-6$ & $7-8-9-10$ \\
\hline - No complain & $\bullet$ Annoying & $\bullet$ Uncomfortable & $\bullet$ Horrible/ \\
- No & - Mild & $\bullet$ Moderate & agonizing \\
compressive/ & compressiv/ & compressive/ & $\bullet$ Severe symptoms \\
cosmetic & cosmetic & cosmetic & (patient can't \\
symptoms & symptoms & symptoms & breathe mainly in \\
& & & supine position) \\
\hline
\end{tabular}

Table (2): Scale for vascularity assessment by Doppler.

\begin{tabular}{llll}
\hline 0 & \multicolumn{1}{c}{2} & \multicolumn{1}{c}{3} \\
\hline - No Doppler & $\bullet$ Doppler signal \\
signal & $\begin{array}{l}\text { Dess than 25\% } \\
\text { lespler signal } \\
\text { of the nodule }\end{array}$ & $\begin{array}{l}\text { between 25\%- } \\
50 \%\end{array}$ & $\begin{array}{c}\text { Doppler signal } \\
\text { more than 50\% }\end{array}$ \\
\hline
\end{tabular}

Table (3): VAS scoring pre-treatment and at 12 months followup.

\begin{tabular}{|c|c|c|c|c|}
\hline \multirow{2}{*}{$\begin{array}{l}\text { Patients } \\
\text { numbers } \\
\text { and age }\end{array}$} & \multicolumn{2}{|c|}{ Pre-treatment score } & \multirow{2}{*}{\multicolumn{2}{|c|}{$\begin{array}{l}\text { Score at } 12 \text { month } \\
\text { post-treatment }\end{array}$}} \\
\hline & A- Compressive A & B- Cosmetic B & & \\
\hline 1 (46ys) & 8 & 5 & 3 & 2 \\
\hline $2(45)$ & 9 & 7 & 4 & 6 \\
\hline $3(46)$ & 7 & 6 & 0 & 3 \\
\hline $4(43)$ & 6 & 5 & 1 & 2 \\
\hline $5(43)$ & 8 & 6 & 2 & 0 \\
\hline $6(51)$ & 9 & 7 & 4 & 6 \\
\hline $7(69)$ & 5 & 3 & 0 & 0 \\
\hline $8(60)$ & 6 & 2 & 1 & 0 \\
\hline $9(55)$ & 8 & 4 & 1 & 0 \\
\hline $10(26)$ & 0 & 6 & 0 & 6 \\
\hline $11(45)$ & 4 & 3 & 0 & 0 \\
\hline 12 (19) & 0 & 7 & 0 & 3 \\
\hline $13(22)$ & 6 & 4 & 1 & 1 \\
\hline $14(42)$ & 7 & 5 & 1 & 1 \\
\hline $15(43)$ & 0 & 8 & 0 & 7 \\
\hline $16(35)$ & 0 & 9 & 0 & 8 \\
\hline $17(66)$ & 7 & 5 & 1 & 1 \\
\hline $18(21)$ & 0 & 5 & 0 & 3 \\
\hline $19(58)$ & 6 & 1 & 2 & 0 \\
\hline $20(39)$ & 8 & 3 & 2 & 0 \\
\hline
\end{tabular}

Table (4): Size difference post-treatment and at 12 months follow-up.

\begin{tabular}{lcc}
\hline $\begin{array}{l}\text { Number of } \\
\text { nodules }\end{array}$ & $\begin{array}{c}\text { Pre-treatment } \\
\text { nodule volume }\end{array}$ & $\begin{array}{c}\text { Volume at } 12 \text { month } \\
\text { post-treatment }\end{array}$ \\
\hline 1 & 15 & 6 \\
2 & 20 & 9 \\
3 & 13 & 6 \\
4 & 12 & 5 \\
5 & 14 & 6 \\
6 & 20 & 8 \\
7 & 12 & 5 \\
8 & 15 & 7 \\
9 & 13 & 6 \\
10 & 14 & 6 \\
11 & 14 & 6 \\
12 & 15 & 7 \\
13 & 12 & 5 \\
14 & 13 & 6 \\
15 & 14 & 6 \\
16 & 12 & 5 \\
17 & 13 & 6 \\
18 & 8 & 3 \\
19 & 9 & 3 \\
20 & 10 & 4 \\
21 & 8 & 3 \\
22 & 10 & 8 \\
23 & 9 & 4 \\
24 & 8 & 3 \\
25 & 9 & 4 \\
26 & 9 & 3 \\
27 & 10 & 4 \\
\hline & &
\end{tabular}

Table (5.1):

\begin{tabular}{llllllll}
\hline & $\mathrm{n}$ Median & 25 Perc & 75 Perc & $\mathrm{Z}$ & $p$ & Sig. \\
\hline Compressive pre: & & & & & & & \\
$\quad$ Pre & 20 & 6 & 1 & 8 & & & \\
$12 \mathrm{M}$ & 20 & 1 & 0 & 2 & $-3.455^{\mathbf{b}}$ & 0.001 & $\mathrm{HS}$ \\
& & & & & & & \\
Cosmetic pre: & & & & & & & \\
$\quad$ Pre & 20 & 5 & 3.25 & 6.75 & & & \\
$\quad 12 \mathrm{M}$ & 20 & 1.5 & 0 & 5.25 & $-3.857 \mathbf{b}$ & 0 & $\mathrm{HS}$ \\
$\quad$ Nod. vol. pre: & & & & & & & \\
$\quad$ Pre & 27 & 12 & 9 & 14 & & & \\
$\quad$ 12M & 27 & $\mathbf{6}$ & 4 & 6 & $-4.565 \mathbf{b}$ & 0 & HS \\
\hline
\end{tabular}

Table (5.2):

\begin{tabular}{|c|c|c|c|c|}
\hline & & $12 \mathrm{M}$ & Pre & Total \\
\hline Compressive: & Count & 17 & 5 & 22 \\
\hline$\bullet 0-2$ & $\%$ & $85.0 \%$ & $25.0 \%$ & $55.0 \%$ \\
\hline \multirow[t]{2}{*}{ • 3-9: } & Count & 3 & 15 & 18 \\
\hline & $\%$ & $15.0 \%$ & $75.0 \%$ & $45.0 \%$ \\
\hline \multirow[t]{2}{*}{ Total: } & Count & 20 & 20 & 40 \\
\hline & $\%$ & $100.0 \%$ & $100.0 \%$ & $100.0 \%$ \\
\hline \multicolumn{5}{|c|}{ Chi-Square Tests. } \\
\hline & & \multicolumn{2}{|c|}{ Value } & $p$ \\
\hline \multicolumn{3}{|c|}{ Pearson Chi-Square } & $45^{\mathrm{a}}$ & .000 \\
\hline
\end{tabular}

Table (5.3):

\begin{tabular}{|c|c|c|c|c|}
\hline & & $12 \mathrm{M}$ & Pre & Total \\
\hline Cosmetic: & Count & 15 & 7 & 22 \\
\hline - $0-4$ : & $\%$ & $75.0 \%$ & $35.0 \%$ & $55.0 \%$ \\
\hline - 5-9: & Count & 5 & 13 & 18 \\
\hline & $\%$ & $25.0 \%$ & $65.0 \%$ & $45.0 \%$ \\
\hline Total: & Count & 20 & 20 & 40 \\
\hline & $\%$ & $100.0 \%$ & $100.0 \%$ & $100.0 \%$ \\
\hline \multicolumn{5}{|c|}{ Chi-Square Tests. } \\
\hline & & \multicolumn{2}{|c|}{ Value } & $p$ \\
\hline \multicolumn{3}{|c|}{ Pearson Chi-Square } & $465 \mathrm{a}$ & 011 \\
\hline
\end{tabular}

Table (5.4):

\begin{tabular}{|c|c|c|c|c|}
\hline & & $12 \mathrm{M}$ & Pre & Total \\
\hline Nod. Vol.: & Count & 26 & 3 & 29 \\
\hline • 3-8: & $\%$ & $96.3 \%$ & $11.1 \%$ & $53.7 \%$ \\
\hline \multirow[t]{2}{*}{ - 9-20: } & Count & 1 & 24 & 25 \\
\hline & $\%$ & $3.7 \%$ & $88.9 \%$ & $46.3 \%$ \\
\hline \multirow[t]{2}{*}{ Total: } & Count & 27 & 27 & 54 \\
\hline & $\%$ & $100.0 \%$ & $100.0 \%$ & $100.0 \%$ \\
\hline \multicolumn{5}{|c|}{ Chi-Square Tests. } \\
\hline & & \multicolumn{2}{|r|}{ Value } & $p$ \\
\hline \multicolumn{3}{|c|}{ Pearson Chi-Square } & $39.401 \mathrm{a}$ & .000 \\
\hline
\end{tabular}




\section{Discussion}

Radiofrequency ablation in treating symptoms of thyroid nodules is gaining worldwide acceptance nowadays. Clear guidelines and consensus recommendations have been discussed in literature in the past few years highlighting how far the technique aids in significantly reducing thyroid nodule volume and relieving most of its associated clinical problems, primarily local and cosmetic issues, as effectively as surgery. In our study a 12 months follow-up showed a $76 \%$ reduction in size and the best clinical outcomes were attained in nodules having a mixed solid and cystic content. This matched previous studies revealing that RFA can downsize thyroid nodule volume by $33-58 \%$ within a month, by $51-85 \%$ at six months following the procedure $[13,21]$, and by $93 \%$ four years following the procedure [23]. Different degrees of decrease in volume can be correlated with the sessions number, which in our study was one for each patient, being 1.8 per patient in other studies [23]

In our study we did not include patients with hyper functioning nodules. However, it has been suggested that reduction in volume has not affected the thyroid function in patients with euthyroid state, yet it has been found to have a role in normalizing TSH levels in some of the patients with hyperfunctioning nodules [24]. On the contrary, in a study by Bernardi et al., only in 33\% of patients with hyperthyroidism, the condition was completely resolved, indicating that surgery is more effective than RFA in treatment of hyperfunctioning nodules [25]. This is concordant with what Deandrea et al., said [21], who reported that RFA controlled thyroid hyperfunction after 6 months in 24\% of patients, same as found by Faggiano et al., [26], who further suggested that $40 \%$ of their cases with hyperfunction and hot nodules were fully controlled at 1 year after RFA. Similarly. Spiezia [15] and colleagues have found that a normalized thyroid function has been met after 2 years of ablation in all of the patients with pretoxic nodules and in 53\% of those having toxic nodules. More studies are required to realize if two RFA sessions would provide a radical cure for nodules that are hyperfunctioning with similar surgical efficacy. Nevertheless, that suboptimal recovery could be attributed to difficulty in ablating the entire nodule and the regrowth of the insufficiently ablated peripheral portion [27]. However; all recent accepted recommendations suggest that the best way to treat functioning autonomous nodules is surgery.

As regards complications encountered in our study, postprocedural pain was rare. Apart from 6 cases with mild pain treated by analgesics, 3 cases ended up with small hematomas treated by compression and topical preparations and one case suffered a transient voice change that subsided within 4 days, there were no cases of permanent voice change or other significant complications like nodule rupture or infection. To prevent thermal nerve injury, undertreating the area near by the recurrent laryngeal nerve also called the danger triangle, while using the moving-shot technique have been suggested.

In addition to its efficacy and safety, Bernardi et al., found that RFA is had much more less cost compared to surgery. They suggested that RFA costs is about 2.6 times less than the surgical option, without taking into consideration the fact that sickleave is significantly shorter and social costs are markedly lower [25] . In fact, in Egypt, surgery being readily available, apparently cheap and included within the health insurance services. Is still more tempting for patients who would not be able to afford the costs of the thyroid electrode.

Previous studies had stated that malignancy might exist in a benign looking nodule. Arora and colleagues assessed 826 thyroid nodule specimens and found 8 malignant (2\%) within benign looking nodules [28]. Also, Park and colleagues found occult papillary carcinomas in $9.2 \%$ of adenomatous goiters and $4.3 \%$ of follicular adenomas [39]. This matches the recent study carried out by Wang and collaborators who showed that around 6\% of benign nodules are found malignant by cytopathology diagnosis after surgical resection [30]. These findings explain how FNAB can miss microscopic foci of malignancy. Therefore, in order to reduce the likelihood of incorrect cytologically benign FNAB it is suggested before RFA [31] to do two FNAB before ablation of the nodules, as done in this study.

Despite the fact that the power of surgery lies in providing a sure pathology and thus accurate diagnosis and cure. However, it is suggested that low-risk cancer of the thyroid has been overtreated, since small papillary cancers can never lead to symptoms or death. A recent papillary thyroid microcarcinoma observation study reported that tumor enlargement and node metastasis were found in $6.5 \%$ and $1.4 \%$ of patients after 5 years of observation [32]. However, still the long term impact of using RFA on malignancy is not well addressed. Although the technique has been successfully used for improvement of clinical symptoms associated with cancer in patients with recurrent cancer thyroid as well as for tumoral locoregional control in cases 
with high risk of surgery or reluctance to repeat surgery [31], long-term monitoring data of radiofrequency ablated benign thyroid nodules is not available regarding those harboring malignant cells and thus how track these cases. For this reason it has been suggested continuing to monitor the ablated nodules at least annually for at least 5 years.

\section{Conclusion:}

Our work, which according to our knowledge had not been preceded with similar studies in Egypt, suggests that RFA is an efficient option to surgery in reducing the size of compressive benign thyroid nodules and their associated problems over a one year follow-up. No complications threatening life were reported. Further studies with recruitment of larger number of patients and long term followup would be necessary in the near future.

\section{Conflict of interest:}

None declared.

\section{References}

1- W.J. MOON, J.H. BAEK, S.L. JUNG, et al.: "Ultrasonography and the ultrasound-based management of thyroid nodules: Consensus statement and recommendations," Korean Journal of Radiology, Vol. 12, No. 1, pp. 1-14, 2011.

2- J.H. BAEK, J.H. LEE, R. VALCAVI, C.M. PACELLA, H. RHIM, and D.G. NA, "Thermal ablation for benign thyroid nodules: Radiofrequency and laser," Korean Journal of Radiology, Vol. 12 No. 5, pp. 525-40, 2011.

3- E.J. HA, J.H. BAEK, and J.H. LEE: "The efficacy and complications ofradiofrequency ablation of thyroid nodules," Current Opinion in Endocrinology, Diabetes and Obesity, Vol. 18, No. 5, pp. 310-4, 2011.

4- L.J. SHEMEN and E.W. STRONG: "Complications after total thyroidectomy," Otolaryngology-Head and Neck Surgery, Vol. 101, No. 4, pp. 472-5, 1989.

5- E. PAPINI, R. GUGLIELMI, G. BIZZARRI, et al.: "Treatment of benign cold thyroid nodules: A randomized clinical trial of percutaneous laser ablation versus levothyroxine therapy or follow-up," Thyroid, Vol. 17, No. 3, pp. 229-35, 2007.

6- Y.J. KIM, J.H. BAEK, E.J. HA, et al.: "Cystic versus predominantly cystic thyroid nodules: Efficacy of ethanol ablation and analysis of related factors," European Radiology, Vol. 22, No. 7, pp. 1573-8, 2012.

7- L. HEGEDÜS: "Therapy: A new nonsurgical therapy option for benign thyroid nodules?" Nature Reviews Endocrinology, Vol. 5, No. 9, pp. 476-8, 2009.

8- R. DIAZ: "Thyroid: HIFU for thyroid nodule ablation," Nature Reviews Endocrinology, Vol. 7, article 631, 2011.

9- O. ESNAULT, B. FRANC, F. MÉNÉGAUX, et al.: "Highintensity focused ultrasound ablation of thyroid nodules: First human feasibility study," Thyroid, Vol. 21, No. 9, pp. $965-73,2011$.
10- B. FENG, P. LIANG, Z. CHENG, et al.: "Ultrasoundguided percutaneous microwave ablation of benign thyroid nodules: Experimental and clinical studies," European Journal of Endocrinology, Vol. 166, No. 6, pp. 1031-7, 2012.

11- MOON W.J., JUNG S.L., LEE J.H., et al.: Benign and malignant thyroid nodules: US differentiation-multicenter retrospective study. Radiology, 247: 762-70, 2008.

12- BAEK J.H., KIM Y.S., LEE D., HUH J.Y. and LEE J.H.: Benign predominantly solid thyroid nodules: Prospective study of efficacy of sonographically guided radiofrequency ablation versus control condition. AJR Am. J. Roentgenol., 194: 1137-42, 2010.

13- JEONG W.K., BAEK J.H., RHIM H., et al.: Radiofrequency ablation of benign thyroid nodules: Safety and imaging follow-up in 236 patients. Eur. Radiol., 18: 1244$50,2008$.

14- HA E.J., BAEK J.H., LEE J.H., KIM J.K. and SHONG Y.K.: Clinical significance of vagus nerve variation in radiofrequency ablation of thyroid nodules. Eur. Radiol., 21: 2151-7, 2011

15- SPIEZIA S., GARBEROGLIO R., MILONE F., et al.: Thyroid nodules and related symptoms are stably controlled two years after radiofrequency thermal ablation. Thyroid, 19: 219-25, 2009.

16- SPIEZIA S., GARBEROGLIO R., Di SOMMA C., et al.: Efficacy and safety of radiofrequency thermalablation in the treatment of thyroid nodules with pressure symptoms in elderly patients. J. Am. Geriatr. Soc., 55: 1478-9, 2007.

17-HEGEDUS L.: Therapy: A new nonsurgical therapy option for benign thyroid nodules? Nat. Rev. Endocrinol., 5: 476-8, 2009.

18- COOPER D.S., DOHERTY G.M., HAUGEN B.R., et al.: Revised American Thyroid Association management guidelines for patients with thyroid nodules and differentiated thyroid cancer. Thyroid, 19: 1167-214, 2009.

19- GOLDBERG S.N., CHARBONEAU J.W., DODD G.D., et al.: Imageguided tumor ablation: Proposal for standardization of terms and reporting criteria. Radiology, 228: 335-45, 2003.

20- SACKS D., McCLENNY T.E., CARDELLA J.F. and LEWIS C.A.: Society of Interventional Radiology clinical practice guidelines. J. Vasc. Interv. Radiol., 14: S199202, 2003.

21- DEANDREA M., LIMONE P., BASSO E., et al.: USguided percutaneous radiofrequency thermal ablation for the treatment of solid benign hyperfunctioning or compressive thyroid nodules. Ultrasound Med. Biol., 34: 784 91, 2008.

22- KIM Y.S., RHIM H., TAE K., PARK D.W. and KIM S.T.: Radiofrequency ablation of benign cold thyroid nodules: Initial clinical experience. Thyroid, 16: 361-7, 2006.

23- LIM H.K., LEE J.H, HA E.J., SUNG J.Y., KIM J.K. and BAEK J.H.: "Radiofrequency ablation of benign nonfunctioning thyroid nodules: 4-year follow-up results for 111 patients," European Radiology, Vol. 23, No. 4, pp. 1044-9, 2013.

24- J.H. SHIN, J.H. BAEK, E.J. HA and J.H. LEE: "Radiofrequency ablation of thyroid nodules: Basic principles and clinical application," International Journal of 
Endocrinology, Vol. 2012, Article ID 919650, 7 pages, 2012.

25- BERNARDI S., DOBRINJA C., FABRIS B., BAZZOCCHI G., SABATO N., ULCIGRAI V., GIACCA M., BARRO E., MANZINI N. and STACUL F.: " Radiofrequency Ablation Compared to Surgery for the Treatment of Benign Thyroid Nodules" Int. J.Endocrinol., 2014: 934595. doi: 10.1155/2014/934595, 2014.

26- FAGGIANO A., RAMUNDO V., ASSANTI A.P., et al.: "Thyroid nodules treated with percutaneous radiofrequency thermal ablation: A comparative study," Journal of Clinical Endocrinology and Metabolism, Vol. 97, No. 12, pp. 4439-45, 2012.

27- BAEK J.H., MOON W.J., KIM Y.S., LEE J.H. and LEE D.: "Radiofrequency ablation for the treatment of autonomously functioning thyroid nodules," World Journal of Surgery, Vol. 33, No. 9, pp. 1971-7, 2009.

28- N. ARORA, T. SCOGNAMIGLIO, B. ZHU, and T.J. FAHEY III: "Do benign thyroid nodules havemalignant potential? An evidencebased review", World Journal of Surgery, Vol. 32, No. 7, pp. 1237-46, 2008.

29- S.H. PARK, E.H. SUH, and J.G.CHI: "Ahistopathologic study on 1,095 surgically resected thyroid specimens," Japanese Journal of Clinical Oncology, Vol. 18, No. 4, pp. 297-302, 1988.

30- C.C.C. WANG, L. FRIEDMAN, G.C. KENNEDY, et al.: "A large multicenter correlation study of thyroid nodule cytopathology.

31- D.G. NA, J.H. LEE, S.L. JUNG, et al.: "Radiofrequency ablation of benign Thyroid nodules and recurrent Thyroid cancers: Consensus statement and recommendations", Korean Journal of Radiology, Vol. 13, No. 2, pp. 117-25, 2012.

32- Y. ITO, A. MIYAUCHI, H. INOUE, et al.: "An observational trial for papillary thyroid microcarcinoma in Japanese patients", World Journal of Surgery, Vol. 34, No. 1, pp. 28-35, 2010.

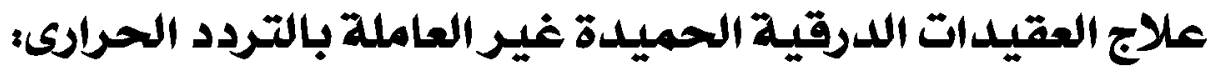

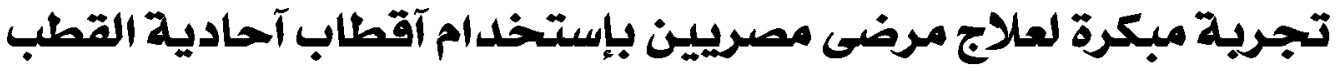

$$
\begin{aligned}
& \text { الفرض: دراسة سلامة ونتائج علاج العقيدات الدرقية الحميدة غير العاملة بالتردد الحرارى. } \\
& \text { الطريقة: } \\
& \text { • قمنا بتقييم rV من عقيدات الفده الدرقية الحميدة فى • مريضاً عوإجوا بالتردد الحرارى وتمت متابعتها لمدة r ا شهراً. } \\
& \text { • ت تم كى العقد بإستخدام القطب المبرد داخلياً. }
\end{aligned}
$$

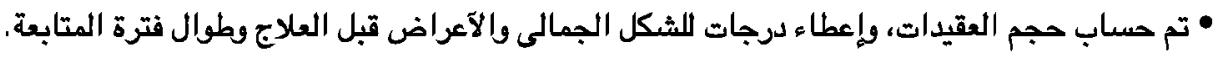

$$
\begin{aligned}
& \text { • تمنا بتقييم جميع العوامل المتعلقة بالفعالية والمضاعفات المبل المبلغ عنها. } \\
& \text { الثتائج }
\end{aligned}
$$

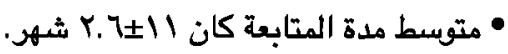

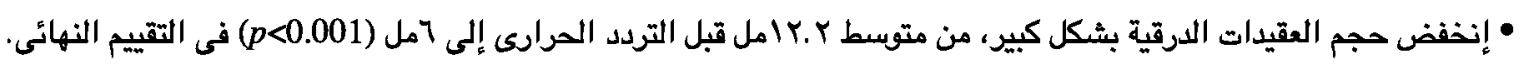

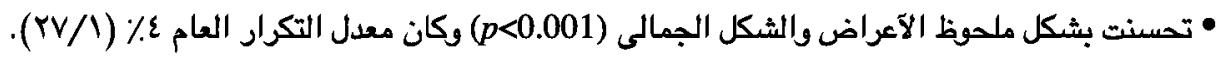

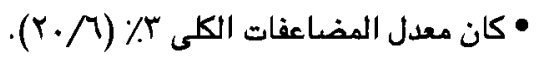

الخلاصة: للتردد الحرارى فعالية ملحوظة فى تقليل حجم العقيدات الدرقية الحميدة الضاغطة وفى علاج المشاكل المتعلقة بحجم العقيدات

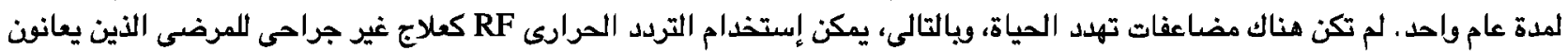

